\title{
Parasites of the freshwater fish trade in Brazil: science metric study ${ }^{1}$
}

\author{
Bruno H. Ueda ${ }^{2 *}$, Letícia C. Karling ${ }^{2}$, Ricardo M. Takemoto ${ }^{2}$ \\ and Gilberto C. Pavanelli ${ }^{2}$
}

\begin{abstract}
Ueda B.H., Karling L.C., Takemoto R.M. \& Pavanelli G.C. 2013. Parasites of the freshwater fish trade in Brazil: science metric study. Pesquisa Veterinária Brasileira 33(7):851-854. Laboratório de Ictioparasitologia, Núcleo de Pesquisas em Limnologia, Ictiologia e Aquicultura, Universidade Estadual de Maringá, Av. Colombo 5790, Maringá, PR 87020-900, Brazil.E-mail: bhueda@gmail.com

This paper presents a science metric study of parasites of fish farming in Brazil, including a significant review of the literature. The methodology used was based on researching articles in three different databases, carried out on May 2012: ISI (Institute for Scientific Information), SciELO (Scientific Electronic Library Online), and Google Academic. The number of articles on fish parasites is mounting (currently over 110), having much increased since 1995. However, the quantity is still low compared with the amount of papers on parasites of fish from natural environments. In Brazil, the farmed fish that have been studied the most are pacu, tilapia and tambaqui. Monogeneans represent the most prevalent group, followed by protozoa and crustaceans. The regions most researched were the southeast and south, making up $84 \%$ of the total literature. The main issue addressed in articles was pathology, followed by treatment and record. In conclusion, the treatment of parasitic diseases of farmed fish in Brazil is still incipient, highlighting the importance and usefulness of management practices to prevent the occurrence of health problems.
\end{abstract}

INDEX TERMS: Fish farms, freshwater fishes, parasites, science metrics, Brazil.

RESUMO.- [Parasitas de peixes de cultivo e de interesse comercial do Brasil: estudo cienciométrico.] Este trabalho apresenta o estudo cienciométrico dos parasitos de peixes de cultivo do Brasil, incluindo significativa revisão da literatura. A metodologia adotada se baseou na pesquisa dos artigos feita no mês de maio de 2012 em três bancos de dados: ISI (Institute for Scientific Information), SciELO (Scientific Electronic Library Online) e Google Acadêmico. 0 número de artigos sobre parasitos de peixes cultivados está aumentando (autalmente mais de 110), havendo um crescimento a partir de 1995. Entretanto o número ainda é baixo se comparado ao número de artigos de parasitos de peixes de ambientes naturais. No Brasil, os peixes de cultivo mais estudados são pacu, tilápia e tambaqui. Os monogenéticos foram os grupos mais prevalente, seguido de protozoários

\footnotetext{
${ }^{1}$ Received on September 26, 2012.

Accepted for publication on May 18, 2013.

${ }^{2}$ Laboratório de Ictioparasitologia, Núcleo de Pesquisas em Limnologia, Ictiologia e Aquicultura, Universidade Estadual de Maringá (UEM), Av. Colombo 5790, Maringá, PR 87020-900, Brazil. *Corresponding author: bhueda@gmail.com
}

e crustáceos. As regiões mais pesquisadass foram o sudeste e sul, perfazendo $84 \%$ da produção bibliográfica total. 0 principal assunto abordado nos artigos foi patologia, seguido por tratamento e registro. Conclui-se que os tratamentos das parasitoses de peixes de piscicultura no Brasil ainda são incipientes, ressaltando a importância e utilidade das boas práticas de manejo para evitar o aparecimento de problemas sanitários.

TERMOS DE INDEXAÇÃO: Piscicultura, peixes de cultivo, parasitos, cienciometria, Brasil.

\section{INTRODUCTION}

Aquaculture is defined as cultivation of aquatic organisms with commercial interest. This activity has a long history, having begun in China 4000 years ago. It is considered very important economically; it aims at efficient production of food, in particular, quality proteins that are essential for human development (Camargo \& Pouey 2005).

According to the Food and Agriculture Organization (FAO), the commodity that has the greatest interest for aquaculture production is fish. In 2008 , the production of 
fish was responsible for $55 \%$ of world aquaculture production, and activity in 2009 contributed about 28.8 million tons of fish, generating sources in the order of 40.5 billion dollars (FAO 2010). In Brazil, according to the report of the Ministério da Pesca e Aquicultura (MPA 2010), aquaculture production in 2009 was 394,340 tonnes; there are plans to double that number by 2015 .

This production in Brazil is considered low, even though the country has large spatial variability in water availability (Leal 1998), with about $20 \%$ of global freshwater (Bizerril \& Primo 2001), and space for implementation of new fisheries projects. This is corroborated by Pavanelli et al. (2008), stating that Brazil is inserted in the international context as a country with great potential for fish farming; as well as having vast territory, its climate favors the cultivation of fish, in particular freshwater species.

On the other hand, extractive fishing cannot meet consumer demand, because scientific data show that if fishing efforts were upped to increase fish production in the same proportion as demand, the natural stocks are in frank depletion (Gulland 1983).

Intensive cultivation is the kind most widely used. As a consequence, fish are subjected to chronic stress, caused by confinement, a situation that starts to facilitate the transmission of pathogens, as there is a lack of space for the fish to develop (Schwedler \& Johnson 2000). It is necessary to mention that infectious, parasitic and nutritional diseases cause serious health and economic problems for fish farmers. In the United States in 1989 a loss of US\$ 23 million was recorded in the rearing of catfish and rainbow trout due to infectious and parasitic diseases. The exact values of the economic losses caused by these agents in fish farms in Brazil are not known (Zimmermann et al. 2001), but it is known that there is great potential to cause significant mortality in farmed fish. Fish are likely to be parasitized by various groups: Amoebae, Flagellata, Apicomplexa, Ciliophora, Myxozoa, Monogenea, Digenea, Cestoda, Nematoda, Acanthocephala, Hirudinea, Crustacea and Mollusca (Eiras et al. 2010).

Unfortunately, as a consequence of the weak performance of our pisciculture, coupled with low natural stocks of fish, the consumption of fish is incipient in Brazil. The World Health Organization (WHO) recommends an average intake of $12 \mathrm{~kg} /$ year per person; however, in Brazil consumption is only $9 \mathrm{~kg} /$ year. It is necessary to emphasize that only the northern region has a high consumption due to the wide availability of fish, coupled with low price. As an example, one can mention the state of Paraná, the fourth in economic and social development of the country, where consumption is only $5.2 \mathrm{~kg}$ /year (IBGE 2011), far below the level recommended by the WHO.

In Brazil the first articles on parasites of fish farming or those with potential for fish farming began in the 1980s. Thus, it is necessary to highlight the contributions of the following researchers, W.A. Boeger, D.R. Brooks, P.S. Cecarelli, J.C. Chubb, C.L.B. Ferraz de Lima, L.B. Figueira, S.C. Cohen, A. Kohn, D.C. Kritsky, G.C. Pavanelli, A.A. Rego, and V.E. Thatcher, among others. The papers of Ceccarelli et al. (1990), Cohen \& Kohn (2009), Figueira \& Ceccarelli (1991) and Martins et al. (2002) can be highlighted for their important contributions to the literature.

This paper presents a science metric study of parasites of fish farming in Brazil, including a bibliographical survey, and updates the corresponding references in respect of aspects of prophylaxis and treatment of these pathogens.

\section{MATERIALS AND METHODS}

The research of the articles was carried out in May 2012 from the databases of ISI (Institute for Scientific Information; www.isiknowledge.com), SciELO (Scientific Electronic Library Online; www. scielo.org) and Google Scholar (http://scholar.google.com.br).

The keywords used in search of the articles make reference to the parasites of fish from fish farms in Brazil and/or those with that potential. We used the following terms, both English and Portuguese: fish parasit*, fish farm, Brazil. For the next searches, the term fish farm was replaced by synonyms, as fee fishing, fish pound, pay-to-fish, aquaculture and pisciculture. The term "parasit*" was used to not exclude synonyms like parasite, parasiting, parasitic. Subsequently the term parasit was replaced by the names of the groups of parasites according to Eiras et al. (2010). After the research had been performed using the databases, surveys were conducted in curriculum vittae Lattes Platform of the Conselho de Desenvolvimento Científico e Tecnológico (CNPq) of the researchers in this area. Then we investigated the Qualis in which the journals that published the articles were analyzed. Qualis is a set of procedures used by Coordenação de Aperfeiçoamento de Pessoal de Nível Superior (CAPES), linked to the Ministry of Education (MEC) and Conselho Nacional de Desenvolvimento Científico e Tecnológico (CNPq) linked to the Ministry of Science, Technology and Innovation (MCTI), in order to assess the quality of articles through analysis of the quality of scientific journals. This survey

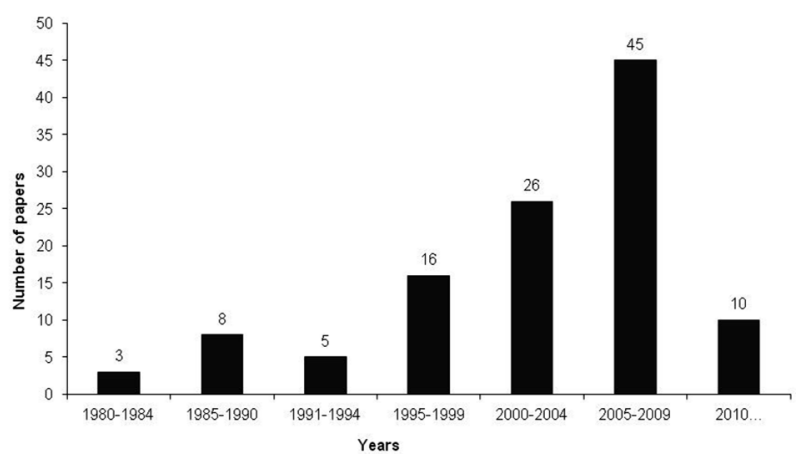

Fig.1. Articles published in the area of parasites of fish farming in Brazil since the 1980s.

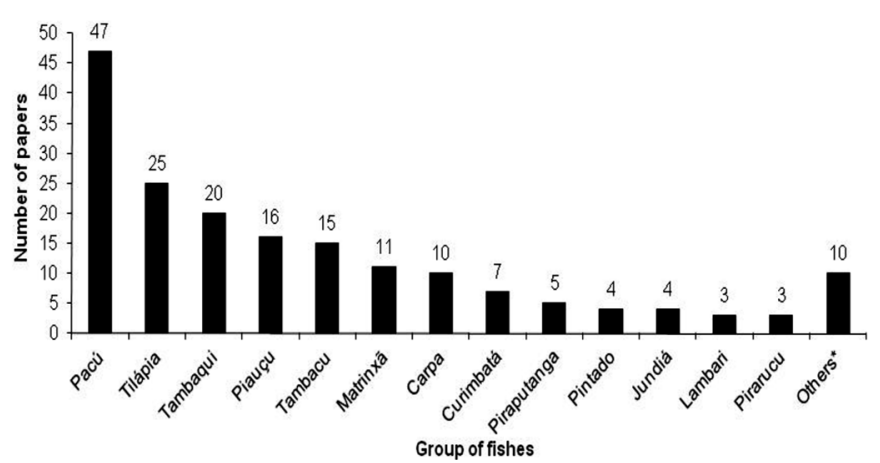

Fig.2. Number of publications in relation to fish species in the specific area of parasites of fish farming in Brazil. *Refers to fish that have been mentioned only in one publication. 
was conducted using the application WebQualis, which frames the journals in different fields of knowledge in strata indicative of quality: A1, the highest standard, followed by A2, B1, B2, B3, B4, B5, and C, with zero weight. For this study, the area that was consulted was Biodiversity.

Among the articles analyzed, the journal name, year of publication, region of Brazil, species of fish, parasite group and subject matter were noted.

The present article refers to the fish using their popular names, which include a series of similar species, mostly belonging to the same genus. Regarding the parasites, in most cases they are reported in relation to the group to which they belong, because the prophylactic and therapeutic procedures are similar for pathogens of the same taxon.

\section{RESULTS}

The number of articles concerning the parasites of farmed fish in Brazil has increased gradually, reaching 113 so far. From 1995 onwards, it is possible to see a significant increase in the number of articles published (Fig.1). Figure 2 shows the most studied fish farming in the country, highlighting the pacu (25\%), followed by tilapia (14\%) and tambaqui (11\%). Figure 3 presents the research by Brazilian region, especially the south and southeast which concentrate $84 \%$ of the total literature. Figure 4 highlights the presence of monogeneans, as the group with the largest number of papers published, followed by protozoa and crustaceans. The main issue addressed in articles was disease caused by parasites (33\%), followed by treatment (23\%), register (19\%) and ecology (17\%) (Fig.5). As shown in Fig.6 and 7 , most articles were published in the journals with Qualis B2 (51\%). Regarding the impact factor of journals, Figure

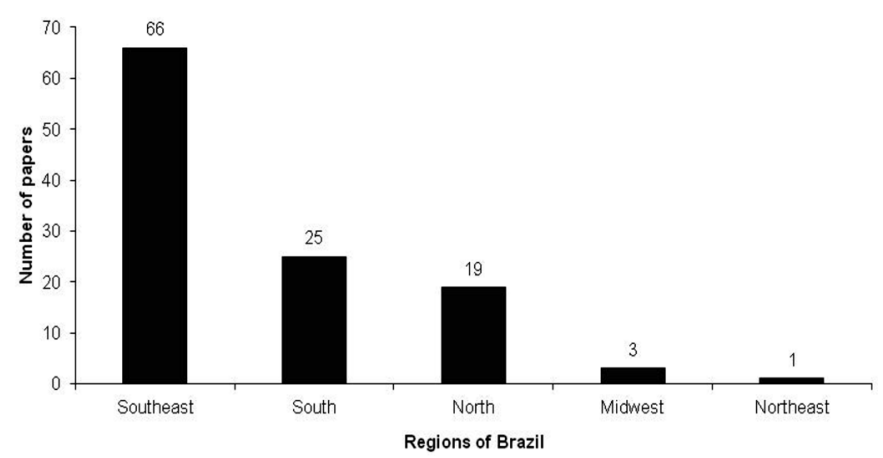

Fig.3. Number of articles published by geographic region of Brazil.

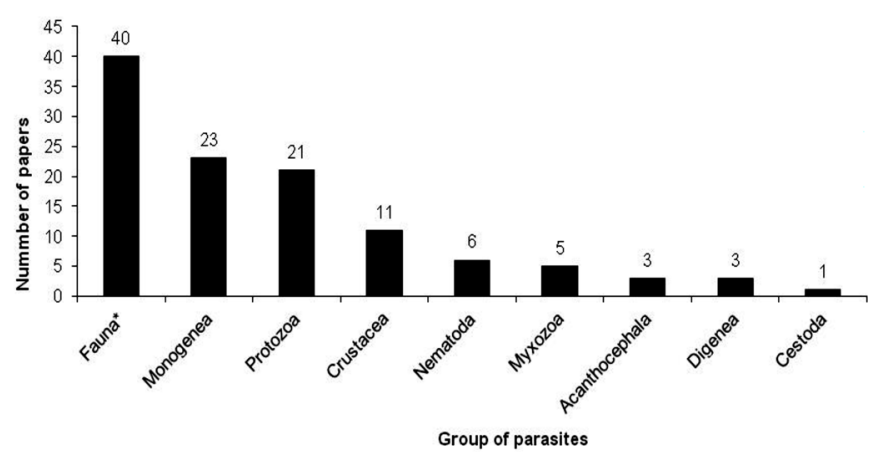

Fig.4. Groups of parasites discussed in the articles of parasites of fish farming in Brazil. *Represents where articles recorded over a zoological group.

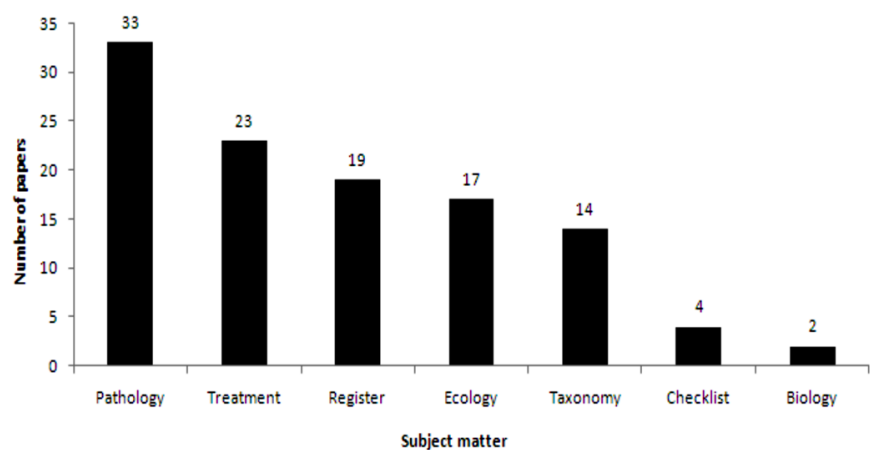

Fig.5. Principal issues addressed in the articles of parasites of fish farming in Brazil.

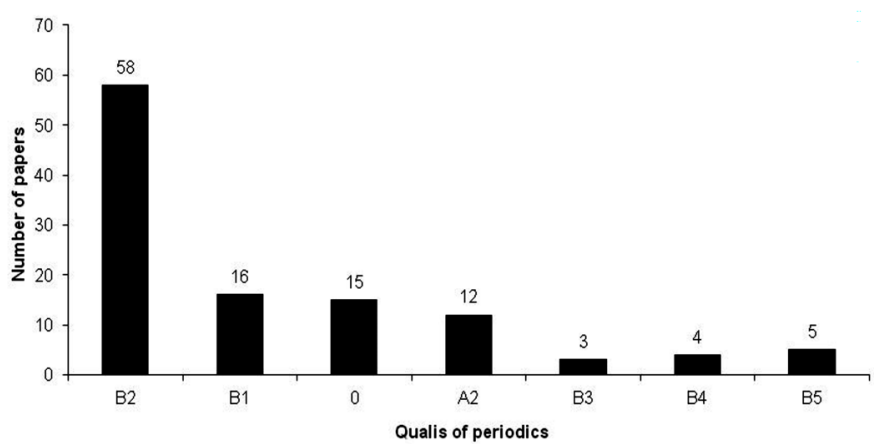

Fig.6. Number of articles from journals and Qualis (area Biodiversity).

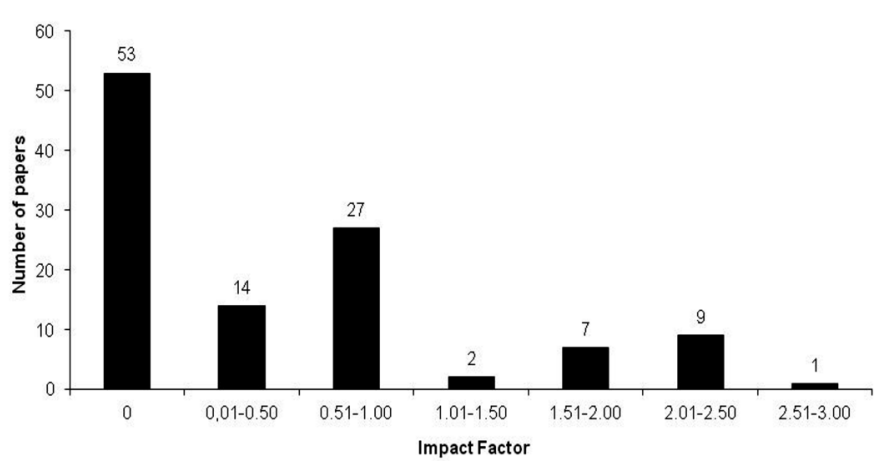

Fig.7. Number of articles and impact factors of scientific journals.

7 shows that almost half of the articles was published in journals without an impact factor (47\%).

\section{DISCUSSION}

The number of articles on the subject of parasitism in farmed fish is still low compared with studies of fish parasitology in natural environments. This may be because fish farming in Brazil is still a recent activity, starting in the 1960s (Agostinho et al. 2007), and, as a consequence, the studies related to the parasites are not numerically significant.

Tilapia and carp are the species that have been introduced to Brazil; they have spread rapidly throughout the country and are currently present in all Brazilian states. One explanation for this may be the introduction and popularization in Brazil of enterprises such as "pay-to-fish". As a consequence, the fish ceased to be marketed only as a food source and began to be part of the entertainment industry. 
This has boosted their market value and the demand for live fish. To attend to the demand for quantity and variety of fish, some fish not previously cultivated and other exotic fish were introduced and/or disseminated to Brazilian hydrographic basins without proper sanitary control (Ostrensky et al. 2008). This not only favored the spread of fish, but also their parasites, making it possible to observe the presence of these pathogens in regions not previously inhabited (Lacerda et al. 2012).

Most of the intellectual production of the country has been in the southern and southeastern areas of Brazil; this is because there is a high concentration of researchers in these states. In addition, in the state of São Paulo this type of enterprise has grown exponentially, from 100 fish farms in 1993 to 1,600 in 1997, helping to explain this phenomenon (Dias 1998).

Information from specialized literature mentions that monogeneans, protozoa and crustaceans are responsible for the highest mortality that occurs in fish farming where the pathogenic agents are parasites (Luque 2004). This is certainly one of the reasons why researchers focus their efforts on studying these subjects, and the fact that most of them have a direct cycle facilitating reproduction and transmission.

In Brazil most of the proposed therapies for the treatment of parasitic diseases of fish are inefficient: first, because drugs have not been developed for the environmental conditions of our country; second, due to the difficulty of administering the procedures; and third, due to the danger of contamination of bodies of water and groundwater (Pavanelli et al. 2008).

Furthermore, the treatment is only effective if an early diagnosis is made, which is not always possible. Moreover, these treatments are usually expensive when compared with the selling price of fish and it is often economically more appropriate to let the fish die without giving the proper therapy (Maximiano et al. 2005). This can explain why literature on pathology exists in greater quantities when compared with treatment; as would be expected for a given pathology there are several treatment options (Neves et al. 2005). This becomes even more evident when we consider the literature on management and prophylactic measures that were included in treatment. Perhaps the scientific community is still focused on understanding first what are the pathological conditions and their resulting epidemiology in order to develop further the most effective treatments.

This number of articles published in national journals with a low or absent impact factor can be explained by the lack of concern of researchers with these old ratings, as only recently CAPES and CNPq started to consider them in evaluation processes of Brazilian scientific production. Moreover, the objective was the dissemination of results in journals accessible to technicians and fish farmers, therefore national journals, and those who described pathologies occurring in species of native and introduced fish.

\section{CONCLUSION}

In conclusion, it is evident that all researchers believe that the treatment of parasitic diseases of farmed fish in Bra- zil is still incipient, empirical and difficult to apply and it is necessary to emphasize the importance and usefulness of management practices to prevent the appearance of health problems.

\section{REFERENCES}

Agostinho A.A., Gomes L.C. \& Pelicice F.M. 2007. Ecologia e Manejo de Recursos Pesqueiros em Reservatórios do Brasil. Editora UEM, Maringá. 275p.

Bizerril C.R.S.F. \& Primo P.B.S. 2001. Peixes de águas Interiores do Estado do Rio de Janeiro. Fundação de Estudos do Mar, Rio de Janeiro. 417p.

Camargo S.G.O. \& Pouey J.L.O.F. 2005. Aquicultura, um mercado em expansão. Revta Bras. Agrociênc. 11(4):393-396.

Ceccarelli P.S., Figueira L.B., Ferraz de Lima C.L.B. \& Oliveira C.A. 1990. Observações sobre a ocorrência de parasitos no CEPTA entre 1983 e 1990. Bolm Técnico CEPTA 3:43-54.

Cohen S.C. \& Kohn A. 2009. On Dactylogyridae (Monogenea) of four species of characid fishes from Brazil. CheckList 5(2):351-356.

Dias E.R.A. 1998. Piscicultura no Estado de São Paulo. Bolm Inf. ABRAPOA 9(15):8-10.

Eiras J.C., Takemoto R.M. \& Pavanelli G.C. 2010. Diversidade dos Parasitos de Peixes de Água Doce do Brasil. Editora Clichetec, Maringá.

FAO 2010. The State of World Fisheries and Aquaculture. Food and Agriculture Organization of the United Nations Roma, Available in <http://www. fao.org/docrep/013/i1820e/i1820e.pdf> Accessed on May 29, 2012.

Figueira L.B. \& Ceccarelli P.S. 1991. Observações sobre a presença de ectoparasitas em pisciculturas tropicais do interior (CEPTA e região). Bolm Técnico CEPTA 4(1):57-65.

Gulland J.A. 1983. Fish Stock Assessment: a manual of basic methods. Vol.1. Editora FAO, Rome.

IBGE 2011. Pesquisa de orçamentos familiares 2008-2009: análise do consumo alimentar pessoal no Brasil. Instituto Brasileiro de Geografia e Estatística, Rio de Janeiro. Available in <http://www.ibge.gov.br/home/ estatistica/populacao/condicaodevida/pof/2008_2009_analise_consumo/pofanalise_2008_2009.pdf> Accessed on May 29, 2012.

Lacerda A.C.F., Takemoto R.M., Tavares-Dias M., Poulin R. \& Pavanelli G.C. 2012. Comparative parasitism of the fish Plagioscion squamosissimus in native and invaded river basins. J. Parasitol. 98(4):713-717.

Leal M.S. 1998. Gestão Ambiental de Recursos Hídricos: princípios e aplicações. Companhia de Pesquisa de Recursos Minerais, Rio de Janeiro. 176p.

Luque J.L. 2004. Biologia, epidemiologia e controle de parasitos de peixes. Revta Bras. Parasitol. Vet. 13(1):161-165.

Martins M.L., Onaka E.M., Moraes F.R., Bozzo F.R., Paiva A.M.F.C. \& Gonçalves A. 2002. Recent studies on parasitic infections of freshwater cultivated fish in the state of São Paulo, Brazil. Acta Sci. Animal Science 24(4):981-985.

Maximiano A.A., Fernandes R.O., Nunes F.P., Assis M.P., Matos R.V., Barbosa C.G.S. \& Oliveira-Filho E.C. 2005. Utilização de drogas veterinárias, agrotóxicos e afins em ambientes hídricos: demandas, regulamentação e considerações sobre riscos à saúde humana e ambiental. Ciênc. Saúde Colet. 10(2):483-491.

MPA 2011. Boletim Estatístico da Pesca e Aquicultura. Ministério da Pesca e Aquicultura, Brasília. Available in<http://www.mpa.gov.br/images/Docs/Informacoes_e_Estatisticas/Boletim\%20Estat\%C3\% ADstico\%20MPA\%202010.pdf> Accessed on May 29, 2012.

Neves D.P., Melo A.L., Linardi P.M. \& Vitor R.W.A. 2005. Parasitologia Humana. $11^{\text {th }}$ ed. Editora Atheneu, Rio de Janeiro. 494p.

Ostrensky A., Borghetti J.R. \& Soto D. 2008. Aquicultura no Brasil: o desafio é crescer. Editora Aprenda Fácil, Brasília. 276p.

Pavanelli G.C., Eiras J.C. \& Takemoto R.M. 2008. Doenças de Peixes: profilaxia, diagnóstico e tratamento. 3aa ed. Editora EDUEM, Maringá. 333p.

Schwedler T.E. \& Johnson S.K. 1999/2000. Responsible care and health maintenance of fish in commercial aquaculture. Anim. Welfare Inf. Cent. Bull. 10:3-4.

Zimmermann S., Moreira H.L.M., Vargas L. \& Ribeiro R.P. 2001. Fundamentos da Moderna Aquicultura. Editora Ulbra. Canoas. 123p. 